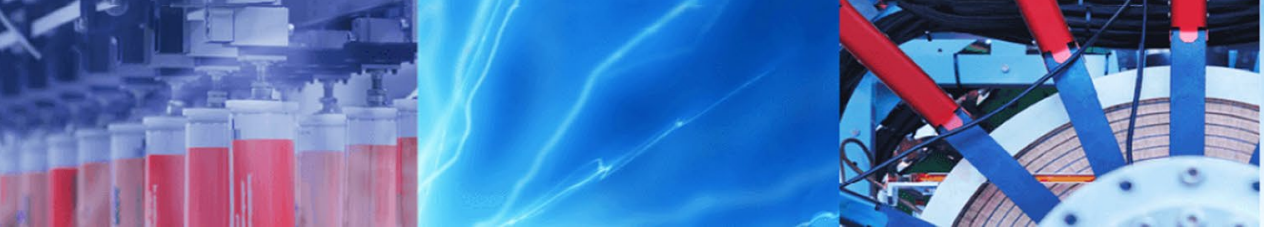

Research Article

\title{
GC-MS analysis of phytocompounds and antihyperglycemic property of Hydrocotyle sibthorpioides Lam.
}

\author{
Ananta Swargiary ${ }^{1}\left[\right.$ Manita Daimari $^{1}$
}

Received: 3 September 2020 / Accepted: 28 December 2020 / Published online: 8 January 2021

(c) The Author(s) $2021 \quad$ OPEN

\begin{abstract}
Hydrocotyle sibthorpioides Lam. is a popular medicinal plant of Assam having several ethnomedicinal values. The present study investigated the metallic content, phytochemical contents, a-amylase, and a-glucosidase enzymes inhibitory property of $H$. sibthorpioides using in-vitro and in-silico methods. Heavy metal contents were analyzed using Atomic Absorption Spectroscopy. GC-MS was used to analyze the phytochemical compounds of the plant. Enzyme inhibition study was carried out by Spectrophotometry methods. The drug-likeness and toxicity properties of the phytocompounds were studied using SwissADME and ADMETlab databases. Docking and molecular visualizations were performed in AutoDock vina and Discovery studio tools. The study found that the extract of $H$. sibthorpioides contains a negligible amount of toxic elements. GC-MS analysis detected four compounds from the methanolic extract of the plant. Biochemical study showed considerable a-amylase and a-glucosidase enzyme inhibitory property of the crude extract of $\mathrm{H}$. sibthorpioides. The $\mathrm{IC}_{50}$ of the plant extracts were found to be $1.27 \mathrm{mg} / \mathrm{ml}$ and $430.39 \mu \mathrm{g} / \mathrm{ml}$ for a-amylase and a-glucosidase enzymes, respectively. All four compounds were predicted to have potential drug-likeness properties with high cell membrane permeability, intestinal absorption, and less toxic effects. The docking study also showed strong binding affinities between the plant compounds and enzymes. Plant compound C2 showed an almost similar binding affinity with the a-amylase enzyme as compared to standard acarbose. The present study, thus, suggests the antihyperglycemic property of $H$. sibthorpioides and can be a potential source of antidiabetic drug candidates.
\end{abstract}

Keywords Hydrocotyle sibthorpioides Lam. · a-Amylase · a-Glucosidase · GC-MS · Docking

\section{Introduction}

Type-2 diabetes (T2D) is a metabolic disorder characterized by high blood glucose leading to several complications including cardiovascular and kidney-related diseases $[1,2]$. According to the WHO report, about 422 million people worldwide have diabetes and about 1.6 million deaths were directly or indirectly caused by diabetes in 2016, making it the seventh leading cause of death globally [3]. There are several control measures to T2D including dietary changes, exercise, and medications. In recent years, there is a growing interest in the dietary and plantbased therapeutic approaches to maintain normal blood glucose levels [4]. Inhibition of carbohydrate metabolizing enzymes is one of the most important chemotherapeutic targets of diabetes treatment. a-Amylase and a-glucosidase enzymes are two of the major carbohydrate metabolizing enzymes inhibition of which slows down the carbohydrate digestion and reduces the rate of glucose absorption, and thus decreases the postprandial plasma glucose level [5].

Plants have been the source of medicines since ancient times. Several modern drugs of present-day use are either directly or indirectly derived from plant sources. Phytomedicines or plant-derived compounds are safer, cheaper, easily available, and sometimes more

Ananta Swargiary, ananbuzoo101@gmail.com | 'Department of Zoology, Bodoland University, Kokrajhar, Assam, India 783370. 
effective than synthetic drugs. Ethnobotanical and pharmacological studies revealed the antidiabetic property of many plants $[6,7]$. There are several ethnomedicinal knowledge attached to this plant and are used in the treatment of a wide range of diseases such as cough, jaundice, dysentery, fever, throat pain, and edema as well as brain tonic [8]. Pharmacological studies have reported antifungal, antibacterial, hepatoprotective, antiproliferative, and tumor growth inhibitory activity of $H$. sibthorpioides $[9,10]$. Several phytochemicals such as quercetin, quercetin 3-galactoside, isorhamnetin, quercetin $3-O-\beta$ D-(6-caffeoylgalactoside), stigmasterol, daucosterol, genistein, and daidzein were reported from the plant [11, 12]. In Assam, H. sibthorpioides is traditionally used to cure stomach-ache, blood dysentery, fever, skin disease, and body ache. The plant is also traditionally used to cure rheumatism, menstrual and digestive problems, and helminth infestations $[13,14]$. In our recent survey study, we found that the tribal community of Kokrajhar district of Assam uses H. sibthorpioides to cure hyperglycemia [15]. Despite its rich ethnomedicinal values, there is no scientific validation of the plant. Therefore, the present study was carried out to validate the antihyperglycemic property of $H$. sibthorpioides using in-vitro and in-silico methods.

\section{Materials and methods}

\subsection{Plant material}

The aerial part of Hydrocotyle sibthorpioides Lam. (Family Apiaceae) was collected from the Tinali area of Kokrajhar district, Assam. The plant sample was identified in the Department of Botany, Bodoland University (specimen voucher number BUBH2018019). After collection, sample plants were washed properly and dried completely in a hot-air oven at $50^{\circ} \mathrm{C}$.

\subsection{Preparation of plant extract}

The dried plant was ground into the powdered form using a mechanical grinder. Plant powder was soaked into $80 \%$ methanol for $72 \mathrm{~h}$ and filtered using Whatman filter paper no. 1. The process was repeated three times and the filtrate obtained was evaporated in a rotary evaporator. After complete evaporation, dry, solid $H$. sibthorpioides methanolic extract (HSME) obtained was stored at $-20^{\circ} \mathrm{C}$ till further use. The process of crude extract was carried out as per the method described in our earlier publication [16].

SN Applied Sciences

A SPRINGER NATURE journal

\subsection{Heavy metal analysis}

Seven elements such as lead $(\mathrm{Pb})$, chromium $(\mathrm{Cr})$, Nickel $(\mathrm{Ni})$, cadmium (Cd), copper (Cu), zinc ( $\mathrm{Zn})$, and manganese $(\mathrm{Mn})$ were analyzed using atomic absorption spectroscopy (AAS, Shimadzu AA-7000). Briefly, $1 \mathrm{~g}$ dry plant powder was digested with conc. $\mathrm{HNO}_{3}$, at $90^{\circ} \mathrm{C}$ for $45 \mathrm{~min}$. The temperature is then increased up to $100^{\circ} \mathrm{C}$ and boiled for $6-7 \mathrm{~h}$ by addition of $5 \mathrm{ml} \mathrm{HNO}_{3}$ till complete digestion of the plant. The process was continued until the extract is colourless. The solution was filtered by Whatman filter no. 1 and diluted to $100 \mathrm{ml}$ of distilled water. The elemental content of plant extract was detected following Zheljazkov and Nielson [17]. The limit of detection and quantification was $0.002-5.0 \mathrm{ppm}$.

\subsection{GC-MS analysis}

The phytochemical composition of the aerial part of $H$. sibthorpioides was analyzed by GC-MS system (Perkin Elmer (USA) make GCMS instrument, Model: Clarus 680 GC \&amp; Clarus $600 \mathrm{C}$ MS comprising a liquid auto-sampler). The Software used in the system was TurboMass Ver. 5.4.2. The capillary column used was'Elite-5MS' having dimensionslength- $60 \mathrm{~m}, \mathrm{ID}-0.25 \mathrm{~mm}$, and film thickness- $0.25 \mu \mathrm{m}$, and the stationary phase is $5 \%$ diphenyl $95 \%$ dimethylpolysiloxane. Helium (99.99\%) was used as carrier gas (i.e., mobile phase) at a flow rate of $1 \mathrm{ml} / \mathrm{min}$. An injection volume of $2 \mu \mathrm{l}$ was employed in splitless mode. Injector and ion-source temperatures were $280^{\circ} \mathrm{C}$ and $180^{\circ} \mathrm{C}$, respectively. The oven temperature was programmed at $60^{\circ} \mathrm{C}$ (for $1 \mathrm{~min}$ ), with an increasing rate of $7{ }^{\circ} \mathrm{C} / \mathrm{min}$ to $200^{\circ} \mathrm{C}$ (hold for $3 \mathrm{~min}$ ) then again increased at rate of $10^{\circ} \mathrm{C} / \mathrm{min}$ to $300^{\circ} \mathrm{C}$ (hold for $5 \mathrm{~min}$ ). The total run time was $\sim 39 \mathrm{~min}$. The solvent delay was kept for $8 \mathrm{~min}$. MS Protocol Mass Spectra was taken in Electron Impact positive (El+) mode at $70 \mathrm{eV}$. A solvent delay of $8 \mathrm{~min}$ was there for $\mathrm{MS}$ scan. Mass range i.e., $\mathrm{m} / \mathrm{z}$ range is 50-600 amu.

Identification of Peaks: Interpretation of the peaks that appeared in the GC Chromatogram were done by library search of the mass spectrum of the corresponding peaks using the database software of National Institute Standard and Technology-2008 (NIST-2008). The mass spectrums of the unknown components were compared with the spectrum known components of the NIST library and the compounds were identified with name, molecular weight, and empirical formula. 


\subsection{Enzyme inhibition study}

\subsubsection{Inhibition of a-amylase activity}

The inhibition of a-amylase enzyme activity of HSME was carried out following Kwon et al. [18] with little modification. The crude plant extract was dissolved in 5\% dimethyl sulfoxide (DMSO). Different concentrations of HSME and reference inhibitor (acarbose) were mixed with $200 \mu \mathrm{l}$ of a-amylase enzyme $(0.5 \mathrm{mg} / \mathrm{ml})$. The assay mixture was incubated at $25^{\circ} \mathrm{C}$ for $10 \mathrm{~min}$. Next, $0.5 \mathrm{ml} 1 \%$ starch solution was added and re-incubated for another $20 \mathrm{~min}$ at $37^{\circ} \mathrm{C}$. After the incubation, $0.5 \mathrm{ml}$ DNS reagent was added to stop the reaction and the assay mixture boiled for $5 \mathrm{~min}$. The reaction mixture was then diluted after adding $5 \mathrm{ml}$ distilled water, and the absorbance (Abs) was measured at $540 \mathrm{~nm}$ in UV/VIS double beam spectrophotometer. The control samples were prepared without any plant extracts/ compounds.

The percent inhibition of a-amylase activity was calculated using the following formula:

Inhibition $(\%)=\frac{(\text { Abs control }- \text { Abs sample })}{\text { Abs control }} \times 100$

Abs control means absorbance of assay mixture without extract and acarbose.

Abs sample means absorbance of assay mixture with extract or acarbose.

\subsubsection{Inhibition of a-glucosidase activity}

a-Glucosidase inhibition assay was carried out following the method of Elya et al. [19]. The plant extract was dissolved in $5 \%$ DMSO and a-glucosidase in $100 \mathrm{mM}$ sodium phosphate buffer, pH6.9. Different concentrations of HSME and acarbose were mixed with $50 \mu \mathrm{l}$ a-glucosidase $(0.5 \mu \mathrm{g} / \mathrm{ml})$ and incubated for $10 \mathrm{~min}$ at $37^{\circ} \mathrm{C}$. Next, $100 \mu \mathrm{l}$ of $5 \mathrm{mM} p$-nitrophenyl-a-D-glucopyranoside was added and incubated for another $20 \mathrm{~min}$ at $37^{\circ} \mathrm{C}$. The reaction was stopped by adding $2 \mathrm{ml}$ of $0.1 \mathrm{M} \mathrm{Na}_{2} \mathrm{CO}_{3}$. The a-glucosidase activity was determined by measuring the absorbance at $405 \mathrm{~nm}$ using a UV/VIS spectrophotometer. Inhibition (\%) of a-glucosidase activity was calculated using Eq. (1).

\subsection{Analysis of drug-likeness and ADMET profile}

The phytochemicals of $H$. sibthorpioides identified by GC-MS analysis were verified for the drug-likeness properties using SwissADME [20] and PubChem database. The drug-likeness property of compounds was evaluated based on Lipinski's rule [21]. Similarly, in-silico absorption, distribution, metabolism, excretion, and toxicity (ADMET) properties of identified compounds were predicted using ADMETlab [22].

\subsection{Molecular docking}

\subsubsection{Preparation of ligands and enzymes}

GC-MS reported compounds of $H$. sibthorpioides were retrieved from the PubChem database. Acarbose was used as a reference inhibitor. The crystal structure of a-amylase (PDB: 2QV4) and a-glucosidase (maltase) (PDB: 2QMJ) enzymes were downloaded from the PDB database (http:// www.rcsb.org/pdb). Downloaded protein structures were cleaned by removing the attached ligands, hetatms, and water molecules. Acarbose was the main co-crystallised ligand with both a-amylase and a-glucosidase enzyme 3D protein structures. Polar hydrogen and energy were added to the cleaned protein structures using AutoDock Tools. The amino acid residues attached to the co-crystallised ligand in the active pocket (site) of protein structures were selected for docking. The active pocket amino acid residues were Trp-59, Gln-63, Gly-104, Asn-105, Val-106, Val-107, Thr-163, Arg-195, Asp-197, His-201, Glu-233, His-299, and Asp-300 for a-amylase and Asp-203, Asp-327, Arg-526, Asp-542 and His-600 for a-glucosidase enzyme.

\subsubsection{Docking}

After the ligands (plant compounds and acarbose) and the target enzymes were prepared, docking was performed in AutoDock Vina [23]. The grid parameters for docking were set as $x, y, z$ size coordinate and grid box centre coordinate i.e., $10.749,48.629,21.111$, and $56,66,60$ for a-amylase enzymes and $-23.755,-5.19,-11.162$, and $40,50,42$, for a-glucosidase enzyme, respectively. The docking was carried out by keeping the default exhaustiveness i.e., 8. Docking output was visualized in Discovery Studio.

\subsection{Statistical analysis}

All the results were expressed as means of three experiments \pm standard deviation (SD), $n=3$. Statistical difference between the extract and reference compound was tested by one-way analysis of variance (ANOVA, $P \leq 0.05$ level) and graphical presentations were prepared in Excel and Origin Pro. 


\section{Results}

\subsection{Heavy metal analysis}

Metallic analysis of $H$. sibthorpioides showed a negligible quantity of heavy metals. Out of the seven important heavy metals ( $\mathrm{Cd}, \mathrm{Mn}, \mathrm{Cr}, \mathrm{Zn}, \mathrm{Pb}, \mathrm{Ni}$, and $\mathrm{Cu}$ ) analyzed; $\mathrm{Cd}$ was not detected in the analysis. $\mathrm{Zn}$ was found to be the highest in concentration $(0.971 \mathrm{ppm})$ followed by $\mathrm{Ni}(0.0472 \mathrm{ppm}), \mathrm{Cr}(0.0459 \mathrm{ppm}), \mathrm{Mn}$ (0.0405 ppm), Cu (0.0229 ppm), and $\mathrm{Pb}(0.0228 \mathrm{ppm})$, respectively.

\subsection{GC-MS analysis}

GC-MS analysis of the methanolic crude extracts of the H. sibthorpioides detected four compounds namely Propanoic acid, 3-nitro-, methyl ester (C1), 5-hepten-3-one, 5-ethyl-4-methyl-(C2), 1-cyclohexyl-2-methyl-2-propanol (C3), and 2-methyl-5-(1-adamantyl)pentan-2-ol (C4). The GC-MS intensities of $\mathrm{H}$. sibthorpioides extract are presented in Fig. 1. The retention time, mol. weight, peak area, and other GC-MS profiles of the identified compounds are presented in Table 1. The 2D structures of the identified compounds are shown in Fig. 2.
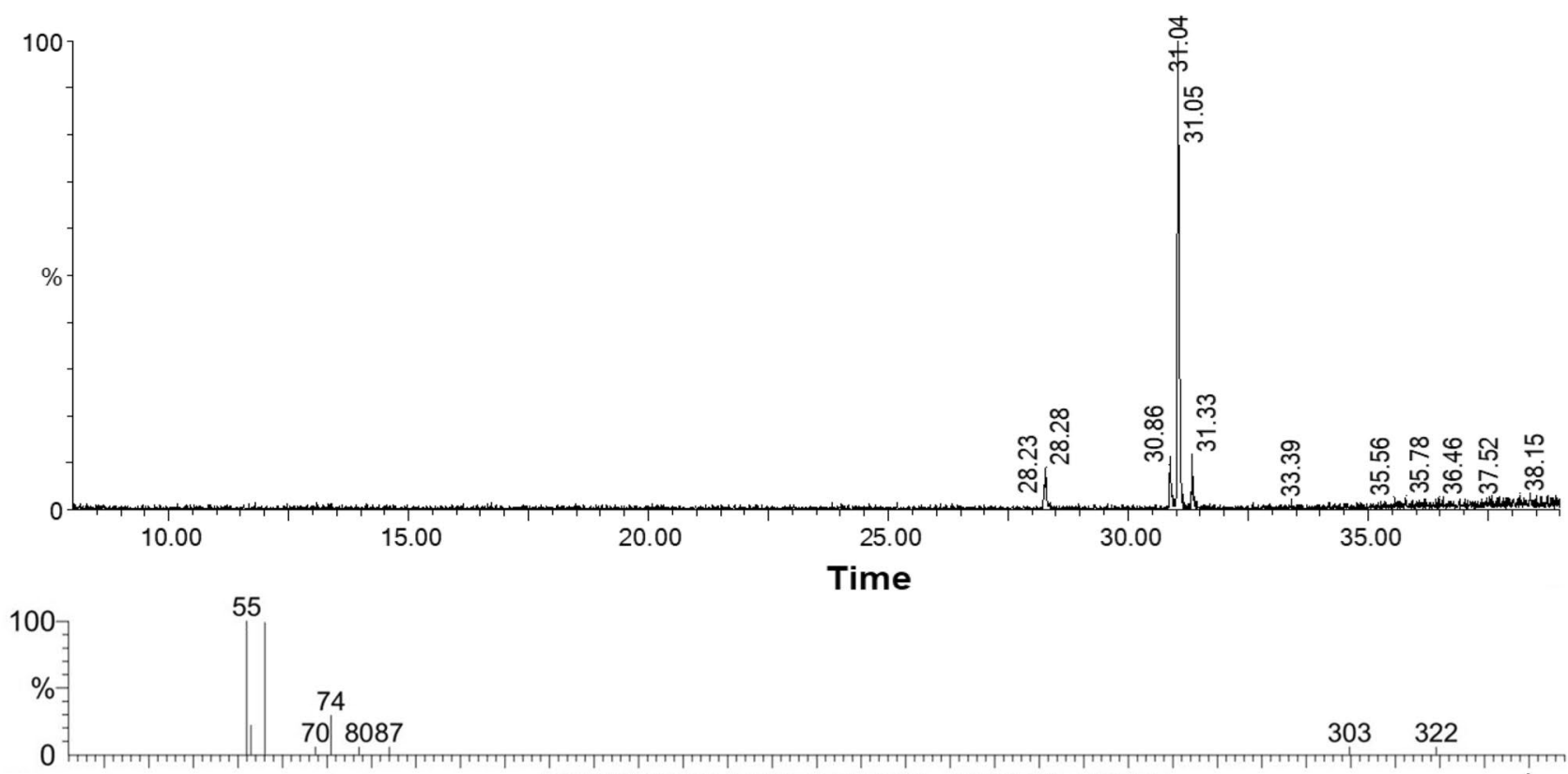

Time

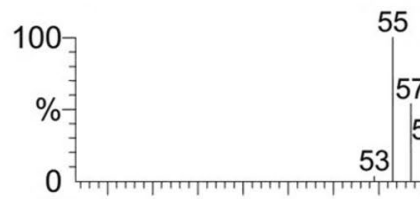

PROPANOIC ACID, 3-NITRO-, METHYL ESTER

$\mathrm{m} / \mathrm{z}$

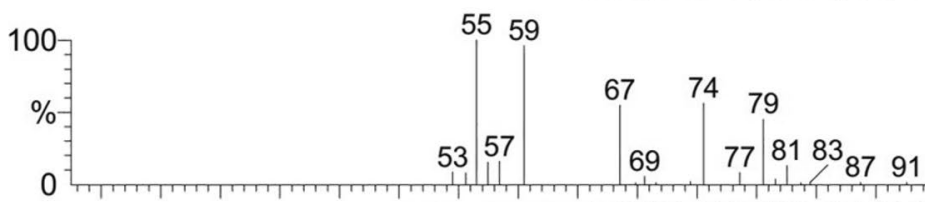

1-CYCLOHEXYL-2-METHYL-2-PROPANOL

$\mathrm{m} / \mathrm{z}$

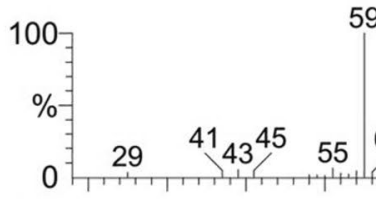

59 124

Fig. 1 GC-MS chromatogram of methanolic extract of Hydrocotyle sibthorpioides 


\subsection{Enzyme inhibition assays}

The a-amylase and a-glucosidase enzyme inhibitory activity of HSME are presented in Fig. 3. The methanolic crude extract of the plant showed concentration-dependent inhibition in both the enzyme activities. The crude extracts of $\mathrm{H}$. sibthorpioides showed stronger inhibitory activity against a-glucosidase enzyme compared to a-amylase. However, statistical analysis ( $P \leq 0.05$ level) showed no significant difference in the enzyme inhibition properties of plant extracts and reference chemical, acarbose. In case of a-amylase enzyme activity, HMSE showed slightly better inhibitory activity compared to the reference compound, acarbose. At the plant concentration of $5 \mathrm{mg} / \mathrm{ml}$, the inhibition of a-amylase was found to be $96.12 \pm 3.86 \%$ and $90.73 \pm 5.19 \%$ for HSME and acarbose, respectively (Fig. 3a). The a-Glucosidase enzyme, on the other hand, showed $73.91 \pm 3.57 \%$ and $96.21 \pm 3.29 \%$ inhibition at $1 \mathrm{mg} / \mathrm{ml}$ of HSME and acarbose, respectively (Fig. 3b). The $\mathrm{IC}_{50}$ values for a-amylase was found to be $1.27 \mathrm{mg} / \mathrm{ml}$ and $1.72 \mathrm{mg} / \mathrm{ml}$ for the plant extract and acarbose, respectively. Similarly, the $\mathrm{IC}_{50}$ value of a-glucosidase enzyme
Table 1 GC-MS properties of compounds identified from Hydrocotyle sibthorpioides

\begin{tabular}{llllll}
\hline Sl. No & Name of the compounds & Retention time & $\mathrm{MW}(\mathrm{g} / \mathrm{mol})$ & Height (\%) & $\mathrm{MF}$ \\
\hline 1 & Propanoic acid, 3-nitro-, methyl ester & 28.277 & 133.1 & 2.760 & $\mathrm{C}_{4} \mathrm{H}_{7} \mathrm{NO}_{4}$ \\
2 & 5-hepten-3-one, 5-ethyl-4-methyl- & 30.873 & 154 & 2.686 & $\mathrm{C}_{10} \mathrm{H}_{18} \mathrm{O}$ \\
3 & 1-cyclohexyl-2-methyl-2-propanol & 31.043 & 156 & 29.752 & $\mathrm{C}_{10} \mathrm{H}_{20} \mathrm{O}$ \\
4 & 2-methyl-5-(1-adamantyl)pentan-2-ol & 31.333 & 236 & 2.289 & $\mathrm{C}_{16} \mathrm{H}_{28} \mathrm{O}$ \\
\hline
\end{tabular}

MW molecular weight, MF molecular formula

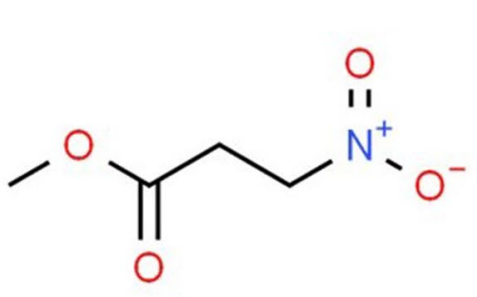

C 1<smiles>CC=C(CC)C(C)C(=O)CC</smiles>

C 2

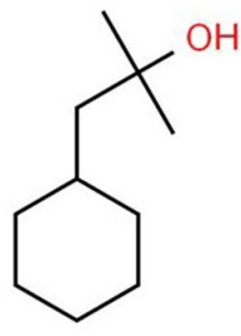

C 3

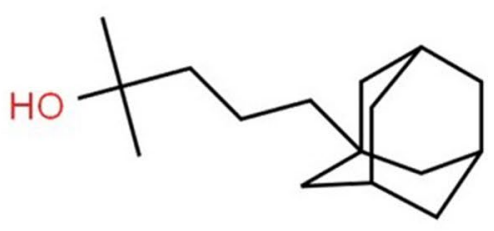

C 4

Fig. 2 Structures of the GC-MS identified compounds from the aerial part of Hydrocotyle sibthorpioides
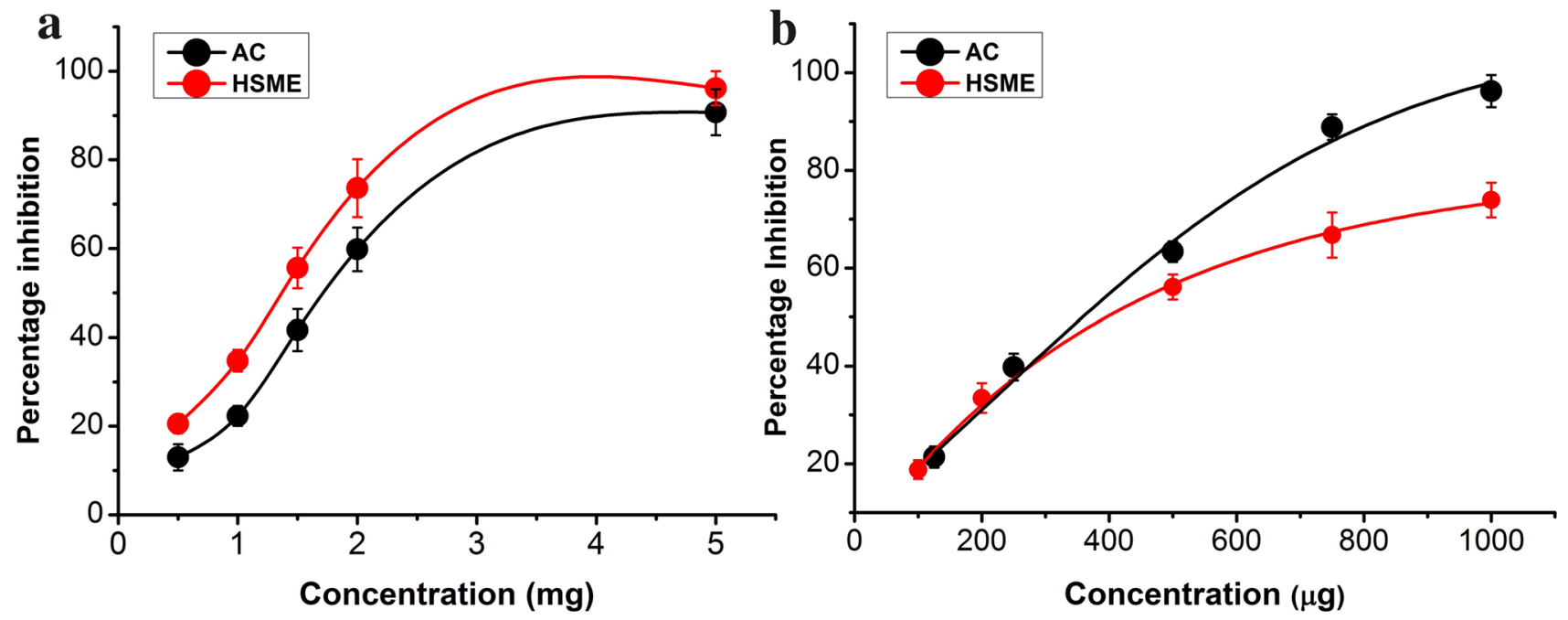

Fig. 3 Activity of a-amylase and a-glucosidase enzymes on exposed to plant extract (HSME) and acarbose (AC). a Inhibition of a-amylase enzyme and $\mathbf{b}$ inhibition of a-glucosidase enzyme. Values were expressed as mean $\pm S D, n=3, P \leq 0.05$ level 
inhibition was found to be $430.39 \mu \mathrm{g} / \mathrm{ml}$ and $304.14 \mu \mathrm{g} /$ $\mathrm{ml}$ for HSME and acarbose, respectively.

\subsection{Analysis of drug-likeness and ADMET profile}

The drug-likeness properties of the identified compounds of HSME are shown in Table 2. According to Lipinski's rule, compound $\mathrm{C} 2$ violated the rule in one parameter (LogP) while the other compounds showed no violation. The reference compound, acarbose, however, violated the rule in all the four parameters. The TPSA of all the compounds were less than $100 \AA^{2}$. The in-silico pharmacological properties and toxicity profile (ADMET) of the identified compounds are represented in Fig. 4. ADMET study showed
Table 2 Drug-likeness properties of Hydrocotyle sibthorpioides phytochemicals

\begin{tabular}{llllllll}
\hline Compounds & PubChem CID & $\begin{array}{l}\text { Mol. Weight } \\
(<500 \mathrm{Da})\end{array}$ & & LogP $(<5)$ & HBD $(<5)$ & HBA $(<10)$ & TPSA $\left(\AA^{2}\right) \begin{array}{l}\text { Lipinski } \\
\text { viola- } \\
\text { tion }\end{array}$ \\
\hline Acarbose & 41,774 & 645.6 & -8.5 & 14 & 19 & 321 & 4 \\
C1 & 547,825 & 133.1 & -0.1 & 0 & 4 & 72.1 & 1 \\
C2 & $5,365,028$ & 154 & 3 & 0 & 1 & 17.1 & 0 \\
C3 & 138,531 & 156 & 3.3 & 1 & 1 & 20.2 & 0 \\
C4 & 548,069 & 236 & 4.9 & 1 & 1 & 20.2 & 0 \\
\hline
\end{tabular}

$H B D$ hydrogen bond donor, HBA hydrogen bond acceptor, TPSA topological polar surface area *LogP negative value means hydrophilic compound

Fig. 4 Heat map of ADMET properties of Hydrocotyle sibthorpioides phytochemicals and reference acarbose (AC). *Range: high, $>8 \mathrm{~h}$; moderate, $>3 \mathrm{~h}$ to $<8 \mathrm{~h}$; low, $<3 \mathrm{~h}$. **Range: High, $>15 \mathrm{ml} / \mathrm{min} /$ $\mathrm{kg}$; moderate, $>5 \mathrm{ml} / \mathrm{min} / \mathrm{kg}$ to $<15 \mathrm{ml} / \mathrm{min} / \mathrm{kg}$; low, $<5 \mathrm{ml} /$ $\mathrm{min} / \mathrm{kg}$
Human Intestinal Absorption

F (20\% Bioavailability)

F (30\% Bioavailability)

Blood-Brain Barrier

P450 CYP1A2 inhibitor

P450 CYP1A2 Substrate

P450 CYP3A4 inhibitor

P450 CYP3A4 substrate

P450 CYP2C9 inhibitor

P450 CYP2C9 substrate

P450 CYP2C19 inhibitor

P450 CYP2C19 substrate

P450 CYP2D6 inhibitor

P450 CYP2D6 substrate

$\mathrm{T} 1 / 2$ (Half-life) $\mathrm{h}^{*}$

Clearance rate $(\mathrm{ml} / \mathrm{min} / \mathrm{kg})^{* *}$

hERG Blockers

Human Hepatotoxicity

Ames Mutagenicity

Skin sensitization

Drug Induced Liver Injury $\begin{array}{lllll}\text { AC } & \text { C1 } & \text { C2 } & \text { C3 } & \text { C4 }\end{array}$

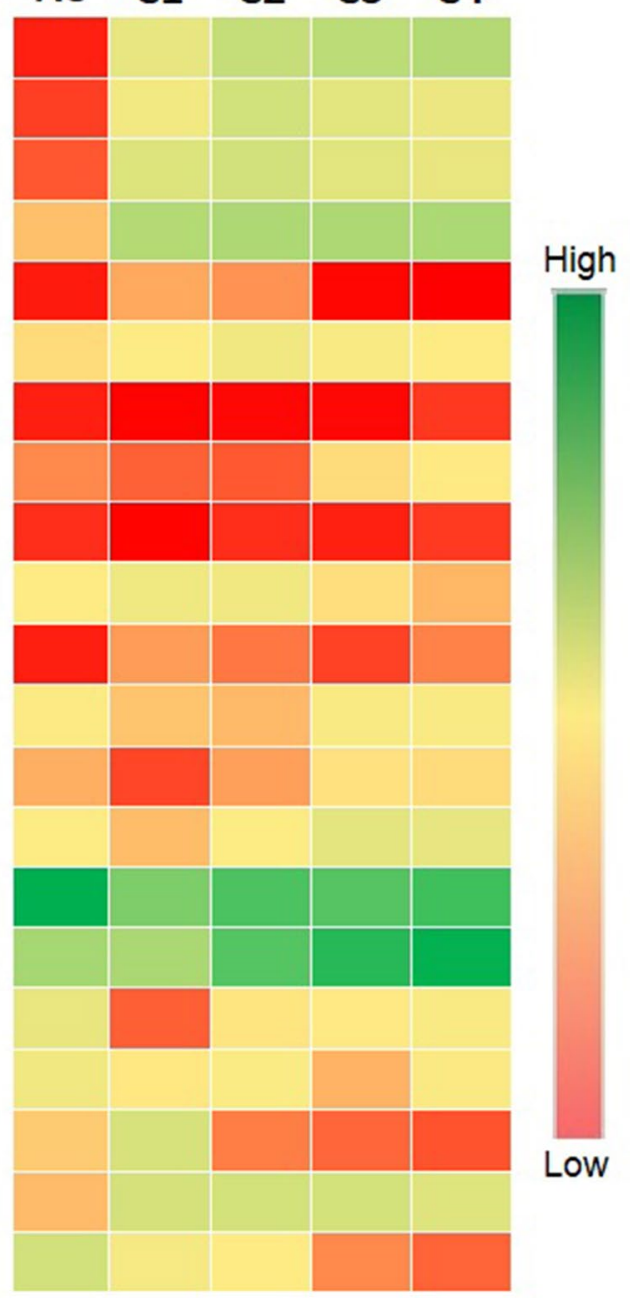


that the identified compounds have moderate to high Gl absorption properties with high blood-brain permeability. Acarbose, on the other hand, showed low Gl absorption and permeability through the blood-brain barrier. All four compounds were found to have low metabolism meaning that the compounds are less metabolized before reaching the target site. However, $\mathrm{C} 2$ showed high interaction with the cytochrome-P450 enzyme system, both as substrate and inhibitor. In terms of toxicity risk, all the compounds showed a low toxicity profile while the reference acarbose showed high liver injury property. The $\mathrm{LC}_{50}$ for acute oral toxicity of the plant compounds $\mathrm{C} 1, \mathrm{C} 2, \mathrm{C} 3$, and $\mathrm{C} 4$ are predicted to be $1880.3,2824,1970.8$, and $4547.516 \mathrm{mg} /$ $\mathrm{kg}$ body weight, respectively. While the reference inhibitor, acarbose was found to be $5874.47 \mathrm{mg} / \mathrm{kg}$.

\subsection{Molecular docking}

The binding energies of all the four compounds and the enzymes are shown in Table 3. The identified compounds of $H$. sibthorpioides showed different binding affinities with the a-amylase and a-glucosidase enzymes. Of the four compounds, C2 showed the strongest binding affinity with binding energy -7.1 and $-6.3 \mathrm{kcal} / \mathrm{mol}$ for a-amylase and a-glucosidase enzymes, respectively. The reference inhibitor, acarbose showed a slightly higher binding affinity $-7.9 \pm 0.22 \mathrm{kcal} / \mathrm{mol}$ and $-7.4 \mathrm{kcal} / \mathrm{mol}$ for a-amylase and a-glucosidase enzymes, respectively. Like enzyme inhibition study, identified phytocompounds showed stronger inhibitory property against a-amylase enzyme. The 2D display of binding interactions between the $\mathrm{C} 2$, acarbose, and the enzymes are shown in Fig. 5. Docking studies revealed that the reference chemical, acarbose interacted with 22 and 17 amino acid residues of a-amylase and a-glucosidase enzymes, respectively. Four amino acid residues of a-amylase, Gln63, Asn105, Thr163, and His299 and five amino acid residues of a-glucosidase, Met331, Tyr301, Gly302, Arg334, and Asp607 showed hydrogen bonding with acarbose (Fig. $5 \mathrm{a}, \mathrm{C}$ ). A total of 13 amino acid residues of both a-amylase and a-glucosidase were found to be interacting with $\mathrm{C} 2$ of $\mathrm{H}$. sibthorpioides methanolic extract. Van der Waals interactions were found to be the major binding interactions between the enzymes and the compound $\mathrm{C} 2$. Of the 13 amino acid residues, seven amino acid residues of a-amylase, His299, Arg195, Asp197, Leu162, Thr163, Leu165, and Gln63 made Van der Waals interactions with C2. Two amino acid residues, Glu233, Asp300 made hydrogen bonding with the compound, while TrpA58, TyrA62, made Pi-Alkyl and Ala198 made alkyl interactions with the compound C2. However, Trp59 is found to be interacting with Pi-sigma bond as well as pialkyl bond with $\mathrm{C} 2$ compound of $\mathrm{H}$. sibthorpioides (Fig. 5b). Similarly, six amino acid residues of a-glucosidase, Asp327, Met444, Asp542, Asp203, Phe450, and Arg526 formed van der Waals interactions with C2 while Trp406, Tyr299, Phe575, and Trp441 formed Pi-Alkyl and Ile364, Ile328 made Alkyl interactions with C2. Amino acid residue, Asp443 is found to be interacting through hydrogen bonding with the compound (Fig. 5d).

\section{Discussion}

H. sibthorpioides is an important medicinal plant of Assam. Despite its rich medicinal values, only a few research publications establish its pharmacological properties. In the present study, we analyzed the heavy metal content, bioactive compounds, and a-amylase and a-glucosidase enzymes inhibitory property of the plant. We also carried out in-silico pharmacokinetics and docking analysis with the GC-MS reported compounds. The present study reveals that the aerial part of $H$. sibthorpioides contains a negligible amount of toxic elements as per the WHO permissible level [24]. In a similar kind of study, Xiao and Xiang [25] studied five trace elements of $H$. sibthorpioides and the content was found in the decreasing order $\mathrm{Fe}>\mathrm{Mn}>\mathrm{Zn}>\mathrm{Cu}>\mathrm{Se}$. GC-MS analysis identified four compounds from the methanolic crude extract of aerial parts of $H$. sibthorpioides. Similarly, UPLC-ESI-MS/MS analysis by Kumari et al. [26] reported the major phenolic content of the plant as catechin, epicatechin, quercetin, and chlorogenic acid. However, we did not find any literature regarding the pharmacological properties of the identified compounds.

The study of pharmacological properties and toxicity is an important prerequisite in the present-day drug
Table 3 Best docking poses and binding affinities of identified plant compounds with a-amylase and a-glucosidase enzymes

\begin{tabular}{lllllll}
\hline Phytocompound & \multicolumn{3}{c}{ a-Amylase $(\mathrm{kcal} / \mathrm{mol})$} & \multicolumn{3}{c}{ a-Glucosidase $(\mathrm{kcal} / \mathrm{mol})$} \\
\hline Acarbose & -7.8 & -8.2 & -7.7 & -7.2 & -7.7 & -7 \\
1-Cyclohexyl-2-methyl & -5.7 & -5.7 & -5.7 & -5.5 & -5.5 & -5.5 \\
2-Methyl-5-(1-adamantyl)pentan & -7.1 & -7.1 & -7.0 & -6.3 & -5.9 & -6.1 \\
5-Hepten-3-one & -5.1 & -5.1 & -5.0 & -5.0 & -5.0 & -5.2 \\
Propanoic acid & -4.5 & -4.4 & -4.3 & -4.7 & -4.9 & -4.7 \\
\hline
\end{tabular}

Docking carried out for three replicates, $(n=3)$ 


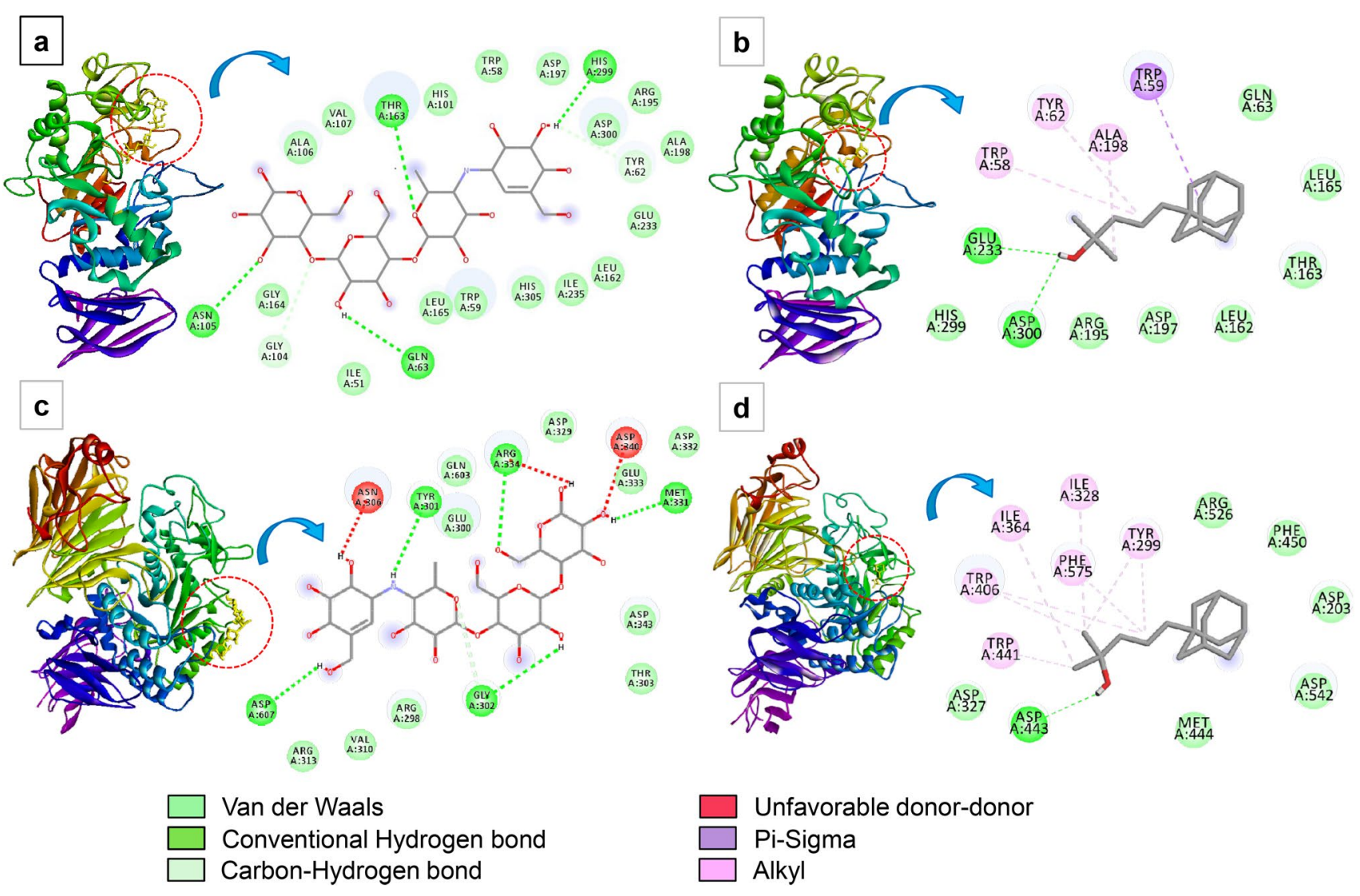

Fig. 5 Docking poses and interactions between enzymes and phytocompounds, a a-amylase-acarbose, b a-amylase-C2, c a-glucosidaseacarbose, and $\mathbf{d}$ a-glucosidase-C2

discovery pipeline. Along with certain physicochemical properties such as molecular mass and size, a drug candidate must also satisfy other properties such as less toxicity, high permeability through the cell membrane, and easy excretion from the body without further deposition [27]. In this regard, Lipinski's rule is an important rule which predicts the in-silico drug-likeness of a compound. According to the rule, a molecule is not considered orally active if it violates two or more of the four rules [28]. From our study, it has been found that all the four compounds identified by GC-MS possess drug-likeness properties. Topological Polar Surface Area is an important property of a compound that determines the permeability of a molecule through the cell membrane. The upper limit of TPSA for a molecule to enter through the cell membrane and the brain is about $140 \AA^{2}$ and $90 \AA^{2}$, respectively $[29,30]$. By adopting the in-silico approaches, the cost and the time factor may be minimized as compared to standard experimental approaches [31]. ADMET analysis showed that the identified compounds have low to moderate ADMET characteristics. Because of its small size and lipophilic property, all the compounds are predicted to be easily absorbed by the GI tract and have high permeability and distribution. ADMET study of the H. sibthorpioides compounds also showed low toxicity property of the compounds suggesting the potentiality of a lead therapeutic compound. According to Lei et al. [32] compounds having LD50 1-50 mg/kg, 51-500 mg/kg, and 501-5000 mg/ $\mathrm{kg}$ are categorized as high, moderate, and low toxicity properties, respectively. Al the four compounds identified from $H$. sibthorpioides were found to have IC50 more than $600 \mathrm{mg} / \mathrm{kg}$ body weight suggesting a low risk of toxicity in the host body.

a-Amylase and a-glucosidase enzymes are two of the most important enzymes of chemotherapeutic drug targets in T2D management and antidiabetic drug designing. The blood-glucose levels can be managed by inhibiting the enzymatic properties of a-amylase and a-glucosidase enzymes. Several medicinal plants are known to have a-amylase and a-glucosidase enzyme inhibitory properties $[33,34]$. The present study revealed that the methanolic crude extract of $H$. sibthorpioides possesses strong inhibitory property against $a$-amylase and a-glucosidase enzymes. Compared to reference acarbose, the crude extract showed better inhibitory activity against a-amylase enzyme. Different solvent extract of Carica 
papaya seed-extracts showed considerable a-amylase and a-glucosidase inhibitory property with $\mathrm{IC}_{50}$ values ranging from 76.96 to $94.63 \mathrm{mg} / \mathrm{ml}$ and 75.78 to $102.4 \mathrm{mg} /$ $\mathrm{ml}$, respectively [35]. Similarly, Khaya senegalensis solvent extracts showed higher a-amylase and a-glucosidase inhibitory property compared to the standard compound, acarbose [36]. With no earlier pharmacological study regarding the antidiabetic property, the present study for the first time reveals $\mathrm{H}$. sibthorpioides to be a potential source of antidiabetic agents. Molecular docking is another aspect of the drug designing approach which is a widely used, relatively fast, and economical computational tool which can be used for virtual screening of a large number of chemicals to screen probable drug candidates [37]. Molecular docking has been used by many researchers to verify the effectiveness of phytochemicals against many target proteins and enzymes [38, 39]. In the present study, compound $\mathrm{C} 2$ of $\mathrm{H}$. sibthorpioides showed almost similar binding affinity to the a-amylase enzyme as compared to acarbose. Human pancreatic a-amylase is a 496 amino acid single polypeptide chain consisting of three structural domains-A, B, and C. Domain-A is the main catalytic unit of the protein with active site residues Asp197, Glu233, and Asp300 [40]. Of the 22 residues interacting with the acarbose, all the three catalytic residues of a-amylase were also found to be involved. Compound $\mathrm{C} 2$ of $\mathrm{H}$. sibthorpioides, however, involved two catalytic residues, Glu233, and Asp300, along with other interacting amino acid residues. Similarly, plant-derived phenolics such as catechin, kaempferol, silibinin, and pelargonidin were found to made potent interactions with the $\operatorname{Tr} 558, \operatorname{Trp} 59$, Tyr62, Gln63, and Leu165 residues including the catalytic residues Asp197, Glu233, and Asp300 of a-amylase enzyme [41]. Ethyl-a-Dglucopyranoside, identified from Terminalia catappa leaf extracts showed van der waals interactions with amino acid residues, Leu328, Trp331, Thr329, Asn316, Arg318, Phe363, and Ala325 of a-amylase enzyme [42]. Similarly, the main catalytic domains of a-glucosidase$\mathrm{N}$-terminal domain consists of 868 residues with Trp441, Ile442, Asp443, Met444, Asn445, and Gln446 as the major catalytic amino acid residues [43]. The present study observed two conventional $\mathrm{H}$-bond interactions between compound C2 and a-amylase enzyme. Similarly, compound $C 2$ showed a slightly weaker binding affinity with a-glucosidase enzyme compared to the reference chemical. Studies by Iheagwam et al. [42] also revealed that the reference drug acarbose showed better binding affinity to a-glucosidase enzyme compared to the T. catappa phytocompound, phytol, which involved van der Waals interactions with Asp282, Asp616, Asp404, Asp443, Arg600, lle441, Leu405, Leu650, and Ser676 amino acid residues. The purified fractions of Simarouba glauca and isolated phytocompound, Cyanidin-3-O-(2'galloyl)-galactoside exhibited stronger a-glucosidase enzyme inhibition both in in-vitro and in-silico study. The major interacting amino acids involved were His245, Pro309, Asp408, 349, Glu304, Arg439, Phe157, - 177, - 310,-231,-311,-158,-300, and Tyr313 for Cyanidin-3-O-(2'galloyl)-galactoside and Pro309, His239, - 279, Asp349, Ser156, Arg439, Thr215, Glu276, Asp214, Phe310, - 300, - 157, - 177, - 311, - 158, Tyr17, and Tyr313 for acarbose, respectively [44]. The biological properties of any plant extracts may be attributed to the phytochemicals present in the plant. Similarly, the molecular docking studies of the present study reflected the results of in-vitro enzyme inhibition study suggesting the inhibitory property of $H$. sibthorpioides against major enzymes linked to Type-2 Diabetes.

\section{Conclusion}

The search for phyto-based medicines and disease treatment has gained momentum over the last few years. $H$. sibthorpioides Lam. is an important medicinal plant in Assam with rich ethnomedicinal values. The present study revealed the a-amylase and a-glucosidase enzymes inhibitory property of $H$. sibthorpioides. Furthermore, molecular docking with identified phytocompounds showed a strong binding affinity with the proteins suggesting the possibility of the antidiabetic drug candidates. However, further investigation needs to be carried out to isolate and purify the active compounds of the plant so that the exact molecular mode of action can be understood.

Acknowledgements There is no specific funding for the present work. However, authors would like to acknowledge the instrumentation facility supported by DST-SERB, Government of India in the form of research project sanctioned to AS. Authors acknowledge the IASST, Boragaon and Biotech Park, IIT, Guwahati for AAS and GC-MS facility. Authors would also like to thank Head, Department of Zoology, Bodoland University for providing necessary facility for carrying out this work.

Author contributions AS-design, docking, manuscript preparation; MD—biochemical analysis, calculation, manuscript preparation.

Availability of data and material NA.

Code availability NA.

\section{Compliance with ethical standards}

Conflict of interest Authors do not have any conflict of interest.

Ethical approval Not applicable (NA).

Consent to participate NA.

Consent for publication Authors give the consent for publication. 
Open Access This article is licensed under a Creative Commons Attribution 4.0 International License, which permits use, sharing, adaptation, distribution and reproduction in any medium or format, as long as you give appropriate credit to the original author(s) and the source, provide a link to the Creative Commons licence, and indicate if changes were made. The images or other third party material in this article are included in the article's Creative Commons licence, unless indicated otherwise in a credit line to the material. If material is not included in the article's Creative Commons licence and your intended use is not permitted by statutory regulation or exceeds the permitted use, you will need to obtain permission directly from the copyright holder. To view a copy of this licence, visit http://creativecommons .org/licenses/by/4.0/.

\section{References}

1. Chudleigh RA, Platts J, Bain SC (2020) Comparative effectiveness of long-acting GLP-1 receptor agonists in type 2 diabetes: a short review on the emerging data. Diabetes Metab Syndr Obes 13:433-438. https://doi.org/10.2147/DMSO.S193693

2. Genco RJ, Graziani F, Hasturk H (2020) Effects of periodontal disease on glycemic control, complications, and incidence of diabetes mellitus. Periodontology 8(3):59-65. https://doi. org/10.1111/prd.12271

3. WHO. Diabetes. https://www.who.int/news-room/fact-sheets/ detail/diabetes. Accessed 12/8/2020

4. Feskens E, Brennan L, Dussort P, Flourakis LL, Mela D, Rabbani N et al (2020) Potential markers of dietary glycemic exposures for sustained dietary interventions in populations without diabetes. Adv Nutr 11(5):1221-1236. https://doi.org/10.1093/advances/ nmaa058

5. Oboh G, Ogunsuyi OB, Ogunbadejo MD, Adefegha SA (2016) Influence of gallic acid on a-amylase and a-glucosidase inhibitory properties of acarbose. J Food Drug Anal 24(3):627-634. https://doi.org/10.1016/j.jfda.2016.03.00

6. Sachan AK, Rao CV, Sachan NK (2019) In-vitro studies on the inhibition of a-amylase and a-glucosidase by hydro-ethanolic extract of Pluchea lanceolata, Alhagi pseudalhagi, Caesalpinia bonduc. Pharmacogn Res 11(3):310-314. https://doi. org/10.4103/pr.pr_31_19

7. Magaji UF, Sacan O, Yanardag R (2020) Alpha amylase, alpha glucosidase, and glycation inhibitory activity of Moringa oleifera extracts. S Afr J Bot 128:225-230. https://doi.org/10.1016/j. sajb.2019.11.024

8. Barukial J, Sarmah JN (2011) Ethnomedicinal plants used by the people of Golaghat district, Assam, India. Int J Med Aromat Plants 1(3):203-211

9. Yu F, Yu F, McGuire PM, Li R, Wang R (2007) Effects of Hydrocotyle sibthorpioides extract on transplanted tumors and immune function in mice. Phytomedicine 14(2-3):166-171. https://doi. org/10.1016/j.phymed.2006.03.010

10. Bordoloi M, Bordoloi PK, Dutta PP, Nath V, Narzary B, Bhuyan PD et al (2016) Studies on some edible herbs: antioxidant activity, phenolic content, mineral content, and antifungal properties. J Funct Foods 23:220-229. https://doi.org/10.1016/j. jff.2016.02.028

11. Shigematsu N, Kouno I, Kawano N (1982) Quercetin 3-(6"-caffeoylgalactoside) from Hydrocotyle sibthorpioides. Phytochemistry 21(8):2156-2158. https://doi.org/10.1016/00319422(82)83079-3

12. Zhang L, Zhang D (2007) Identification of the chemical constituents from Hydrocotyle sibthorpioides. J Guangdong Coll Pharm 23(5):10-11
13. Gogoi M, Saikia BM, Dutta M (2019) Use of medicinal plants in traditional health care practices by tribes of Dhemaji district, Assam, India. Int J Herb Med 7(5):01-06

14. Swargiary A, Roy MK, Daimari M (2019) Survey and documentation of putative anthelmintic plants used in ethnomedicinal systems of tribal communities of Baksa District of Assam. Med Plants Int J Phytomed Relat Ind 11(4):363-374. https://doi. org/10.5958/0975-6892.2019.00048.0

15. Daimari M, Roy MK, Swargiary A, Baruah S, Basumatary S (2019) An ethnobotanical survey of antidiabetic medicinal plants used by the Bodo tribe of Kokrajhar district, Assam. Indian J Trad Know 18(3):421-429

16. Swargiary A, Daimari A, Daimari M, Basumatary N, Narzary E (2016) Phytochemicals, antioxidant, and anthelmintic activity of selected traditional wild edible plants of lower Assam. Indian J Pharmacol 48(4):418-423. https://doi.org/10.4103/02537613.186212

17. Zheljazkov VD, Nielson NS (1996) Effect of heavy metals on peppermint and cornmint. Plant Soil 178(1):59-66. https://doi. org/10.1007/BF00011163

18. Kwon Y, Apostolidis E, Shetty K (2008) Inhibitory potential of wine and tea against a-amylase and a-glucosidase for management of hyperglycemia linked to type-2 diabetes. J Food Biochem 32(1):15-31. https://doi.org/10.111 1/j.1745-4514.2007.00165.x

19. Elya B, Basah K, Munim A, Yuliastuti W, Bangun A, Septiana EK (2012) Screening of a-glucosidase inhibitory activity from some plants of Apocynaceae, Clusiaceae, Euphorbiaceae, and Rubiaceae. J Biomed Biotechnol. https://doi. org/10.1155/2012/281078

20. Daina A, Michielin O, Zoeteb V (2017) SwissADME: a free web tool to evaluate pharmacokinetics, drug-likeness and medicinal chemistry friendliness of small molecules. Sci Rep 7:42717. https://doi.org/10.1038/srep42717

21. Lipinski CA (2004) Lead- and drug-like compounds: the ruleof-five revolution. Drug Discov Today 1(4):337-341. https:// doi.org/10.1016/j.ddtec.2004.11.007

22. Dong J, Wang N, Yao Z, Zhang L, Cheng Y, Ouyang D et al (2018) ADMETlab: a platform for systematic ADMET evaluation based on a comprehensively collected ADMET database. J Cheminform 10:29. https://doi.org/10.1155/2012/281078

23. Trott O, Olson AJ (2010) AutoDock Vina: improving the speed and accuracy of docking with a new scoring function, efficient optimization, and multithreading. J Comput Chem 31(2):455461. https://doi.org/10.1002/jcc.21334

24. Arnott JA, Planey SL (2012) The influence of lipophilicity in drug discovery and design. Expert Opin Drug Discov 7(10):863-875. https://doi.org/10.1517/17460441.2012.71436 3

25. Xiao Y, Xiang W (2013) Determination of trace elements in Hydrocotyle sibthorpioides Lam. of Kaili. Med Plant 3(3):23-25. https:// doi.org/10.1080/07391102.2018.1520149

26. Kumari S, Elancheran R, Kotoky J, Devi R (2016) Rapid screening and identification of phenolic antioxidants in Hydrocotyle sibthorpioides Lam. by UPLC-ESI-MS/MS. Food Chem 203:521529. https://doi.org/10.1016/j.foodchem.2016.02.101

27. DiMasi JA, Hansen RW, Grabowsk HG (2003) The price of innovation: new estimates of drug development costs. J Health Econ 22(2):151-185. https://doi.org/10.1016/S0167-6296(02)00126-1

28. Guan L, Yang H, Cai Y, Sun L, Di P, Li W et al (2019) ADMET-scorea comprehensive scoring function for evaluation of chemical drug-likeness. Med Chem Comm 10(1):148-157. https://doi. org/10.1039/C8MD00472B

29. Matsson $P$, Kihlberg $J$ (2017) How big is too big for cell permeability? J Med Chem 60(5):1662-1664. https://doi.org/10.1021/ acs.jmedchem.7b00237 
30. Hodgson J (2001) ADMET_turning chemicals into drugs. Nat Biotechnol 19(8):722-726. https://doi.org/10.1038/90761

31. Kazeem MI, Adamson JO, Ogunwande IA (2013) Modes of inhibition of a-amylase and a-glucosidase by aqueous extract of Morinda lucida Benth leaf. BioMed Res (Article ID: 527570). https ://doi.org/10.1155/2013/527570

32. Lei T, Li Y, Song Y, Li D, Sun H, Hou T (2016) ADMET evaluation in drug discovery: 15 . Accurate prediction of rat oral acute toxicity using relevance vector machine and consensus modeling. J Cheminform 8:6. https://doi.org/10.1186/s13321-016-0117-7

33. Somtimuang C, Olatunji OJ, Ovatlarnporn C (2018) Evaluation of in-vitro a-amylase and a-glucosidase inhibitory potentials of 14 medicinal plants constituted in Thai folk antidiabetic formularies. Chem Biodivers 15(4):e1800025. https://doi.org/10.1002/ cbdv.201800025

34. Yang Z, Huang W, Zhang J, Xie M, Wang W (2019) Baicalein improves glucose metabolism in insulin resistant HepG2 cells. Eur J Pharmacol 854:187-193. https://doi.org/10.1016/j.ejpha r.2019.04.005

35. Agada R, Usman WA, Shehu S, Thagariki D (2020) In-vitro and in-vivo inhibitory effects of Carica papaya seed on a-amylase and a-glucosidase enzymes. Heliyon 6(2020):e03618. https:// doi.org/10.1016/j.heliyon.2020.e03618

36. Ibrahim MA, Koorbanally NA, Islam MS (2014) Antioxidative activity and inhibition of key enzymes linked to type-2 diabetes (a-glucosidase and a-amylase) by Khaya senegalensis. Acta Pharm 64(3):311-324. https://doi.org/10.2478/acph-2014-0025

37. Ghaedi N, Pouraboli I, Askari N (2020) Antidiabetic properties of hydroalcoholic leaf and stem extract of Levisticum officinale: an implication for a-amylase inhibitory activity of extract ingredients through molecular docking. Iran Iran J Pharm Res 19(1):231-250. https://doi.org/10.22037/ijpr.2020.15140.12901

38. Perumal O, Peddakotla S, Suresh S, Chandramouli GVP, Pydisetty $Y$ (2016) a-Glucosidase inhibitory activity, molecular docking, QSAR and ADMET properties of novel 2-aminophenyldiazenyl-4H-chromene derivatives. J Biomol Struct
Dyn 35(12):2620-2630. https://doi.org/10.1080/07391 102.2016.1227278

39. Swargiary A, Verma AK, Singh S, Roy MK, Daimari M (2021) Antioxidant and antiproliferative activity of selected medicinal plants of lower Assam, India: an in-vitro and in-silico study. AntiCancer Agents ME 21(2):267-277. https://doi.org/10.2174/18715 20620666200719000449

40. Brayer GD, Luo Y, Withers SG (1995) The structure of human pancreatic alpha-amylase at 1.8 A resolution and comparisons with related enzymes. Protein Sci 4(9):1730-1742. https://doi. org/10.1002/pro.5560040908

41. Rasouli H, Hosseini-Ghazvini SM, Abidi H, Khodarahmi R (2017) Differential a-amylase/a-glucosidase inhibitory activities of plant-derived phenolic compounds: a virtual screening perspective for the treatment of obesity and diabetes. Food Funct 8(5):1942-1954. https://doi.org/10.1039/c7fo00220c

42. Iheagwam FN, Israel EN, Kayode KO, De Campos OC, Ogunlana OO, Chinedu SN (2019) GC-MS analysis and inhibitory evaluation of Terminalia catappa leaf extracts on major enzymes linked to diabetes. Evid Based Complement Alternat Med (ID 6316231). https://doi.org/https://doi.org/10.1155/2019/6316231

43. Sim L, Quezada-Calvillo R, Sterchi EE, Nichols BL, Rose DR (2008) Human intestinal maltase-glucoamylase: crystal structure of the n-terminal catalytic subunit and basis of inhibition and substrate specificity. J Mol Biol 375(3):782-792. https://doi. org/10.1016/j.jmb.2007.10.069

44. Mugaranja KP, Kulal A (2020) Alpha glucosidase inhibition activity of phenolic fraction from Simarouba glauca: an in-vitro, in-silico and kinetic study. Heliyon 6(7):e04392. https://doi. org/10.1016/j.heliyon.2020.e04392

Publisher's Note Springer Nature remains neutral with regard to jurisdictional claims in published maps and institutional affiliations. 